\title{
PLASTER REINFORCEMENT WITH FIBERS OBTAINED FROM THE RECYCLE OF CONSTRUCTION AND DEMOLITION WASTE
}

\section{Authors: S. Romaniega Piñeiro (1) and M. Del Rio Merino (2)}

(1) Technical University of Madrid. School of Building Engineering. s.romaniega@gmail.com

(2) Technical University of Madrid. School of Building Engineering

\section{ABSTRACT}

The main objective of this research is to study the feasibility of recycling fibres from construction and demolition waste (C\&DW) as an alternative material to chopped glass fibres which are used today as reinforcing elements in the prefabricated plaster. To do this, sets of samples are made with rockwool and different percentages of combinations between water / plaster. These series are repeated by changing the additive $\mathrm{E}$ glass fibre length of $25 \mathrm{~mm}$ to make a comparative analysis with respect to the series infused with rockwool.

Key words: fibres, rockwool, recycling, C\&DW, plaster.

\section{INTRODUCTION}

\subsection{Construction, environment and sustainability}

The First Earth Summit [1] was an important milestone in the field of the environment. This meeting represents a reference to a new way of perceiving the future and also incorporates awareness about the sustainability in broader terms. A key contribution of the meeting is called Agenda 21 [2], which we consider today a reference for the implementation of sustainable development.

The Johannesburg Reunion 2002 [3] was presented as a great opportunity to assess progress in the actions for the implementation of national strategies for sustainable development, as established by aforementioned Agenda 21. The most notable difference between the previous meetings and Johannesburg, experts say, is that in 2002 the knowledge of our planet was broader, so we should be more aware of the damage caused to it. Nevertheless, the success or failure of the meeting is under discussion.

\subsection{Construction and demolition waste}

The document that currently regulates the construction and demolition of waste at a national level is the Royal Decree 105/2008, of February 1, by regulating the production and management of construction and demolition waste [4].

This Royal Decree was established as a cornerstone of Spanish policy on C\&DW. It is expected to contribute to sustainable development in the construction sector, which is an important sector for the Spanish economy. 


\section{OBJECTIVE}

The main goal of this research is to study the feasibility of using fibres from the recycling of C\&DW (with the intention to exploit the properties that the fibres have when they are sent to the flow of construction and demolition waste) as an alternative material to the fibres currently used as reinforcing elements in the prefabricated plaster.

\section{BACKGROUND}

\subsection{Reinforced plaster}

The fibres are used from years ago to strengthen brittle materials (mud bricks). In general, strengthening of materials works by improving physical-mechanical behavior of the matrix. The behaviour of these compounds depends, firstly, on the type of fibre added, and then on other factors such as percentage of fibre, fibre length, orientation, surface of the fibre.

\subsubsection{Reinforced plaster with natural fibres}

Several references have been found concerning the addition of plaster reinforced with natural fibre [5] [6] [7]. The short fibres used are cellulose, sisal and hemp, but in all of them, the best results were obtained with sisal fibre. [8].

\subsubsection{Reinforced plaster with artificial fibres}

Of the aforementioned fibres, the polymeric fibres [9] [10] and the glass fibres [11] [12] [13] [14] are the more suitable for addition to the plaster as reinforcement. The rest of them are excessively expensive and they have higher mechanical properties than plaster. Furthermore, glass fibres are the most commonly used fibres as reinforcement in the prefabricated plaster.

\subsection{Infused plaster with fibres that come from recycling}

Previous references were found regarding the addition of materials that come from recycling in a plaster matrix [15] [16]; but no references have been found regarding to the use of fibres from recycling, specifically in a plaster matrix.

\section{EXPERIMENTAL METHOD}

\subsection{Materials used}

Different test plaster pieces are made using the following materials: plaster E-35, rockwool from the recycling process and fibreglass of $25 \mathrm{~mm}$. Rockwool is marketed primarily as sheet panel, rigid, or semirigid, joined with different types of resins such as phenolic resins or thermosetting or fireproof, with or without coating. They can also be found supplied in roll form or in bulk. This rockwool obtained from recycling is made with a plate shape of $5.4 \mathrm{~mm}$ thickness and bonded with resin.

\subsection{Preparation of plaster samples}

In the first phase, two series of plaster samples for reference are made of plaster E-35, with a relation between water / plaster $=0.6$. 
Subsequently, in a second phase, series of plaster samples are made with plaster E-35 and relation $\mathrm{W} / \mathrm{P}=0.6$ and the following proportions of rockwool that come from recycling, $1 \%, 1.5 \%, 2 \%, 2.5 \%$, $3 \%, 3.5 \%$ and $4 \%$.

Finally, in third step, and to achieve the main objective, the results obtained with plaster series E-35, $\mathrm{W} / \mathrm{P}=0.6$ and different percentages of rockwool from the recycling $(1 \%, 1.5 \%, 2 \%, 2.5 \%, 3 \%$, $3.5 \%$ and $4 \%$ ), are compared with the series of plaster obtained with $\mathrm{E}-35$, the ratio $\mathrm{W} / \mathrm{P}=0.6$ and different percentages of fibreglass of $25 \mathrm{~mm}(0.5 \%, 1 \%, 1.5 \%, 2.5 \%, 3 \%, 3.5 \%$ and $4 \%)$.

\subsection{Tests carried out}

There are two types of tests: mechanical tests for determining the resistance to bending and compression of the plaster samples, and a test for determining the surface hardness of them, called Shore C. All of them are following the Spanish standards [17].

\section{RESULTS}

\section{1. $\quad 1^{\text {st }}$ Phase: reference samples}

The following table (table 1) shows the average results obtained for the series of tests in the four types of tests performed.

table 1. "Results of the samples for reference"

\begin{tabular}{|l|l|l|l|l|}
\hline RELATION W/P & HARDNESS "SHORE C" & WEIGHT & BENDING STRENGH & $\begin{array}{l}\text { COMPRESSIVE } \\
\text { STRENGHT }\end{array}$ \\
\hline 0,6 & 92,1 & 309,99 & 7,514 & 17,788 \\
\hline
\end{tabular}

\section{2. $\quad 2^{\text {nd }}$ Phase: plaster samples infused with rockwool that comes from recycling}

"Shore C" hardness is increased till around $8 \%$ with $1 \%, 1.5 \%, 2 \%$ and $2.5 \%$ of addition. After addition of $2.5 \%$ the hardness begins to descend as it increases the\% addition.

The weight falls with respect to the reference series. This decrease increases as the percentage of addition of rockwool gets bigger.

The bending strength is decreased by about $5 \%$ for the percentages of adding rock wool of $2.5 \%$, $3 \%$ and $3.5 \%$.

The value of results average of compressive strength obtained exceeds the compressive strength of the reference series, reaching the maximum value with addition of $3 \%$ increasing in this case $12.51 \%$.

\section{3. $\quad 3^{\text {rd }}$ Phase: Plaster series additived with E glass fibre}

Finally the results of the series infused with glass fibre are analyzed, comparing these results with the series of reference.

The results of the surface hardness obtained are lower than the ones obtained for the series of reference. They decrease by $6 \%$ to $1.5 \%$ addition. The weight is bigger for all the percentages of addition, reaching a $3.5 \%$ of increase for the series infused with $2.5 \%$ of fibreglass. 
The results obtained in the testing of bending strength are increasing as it increases the percentage of addition. Adding a percentage of E-glass fibre $4 \%$, the bending strength is increased by $50 \%$. Furthermore, after done the bending strength test, the fracture surface is completely sewn with the fibres.

The results obtained in the compression test are lower than the ones obtained for the series for reference. The maximum value is obtained by adding $4 \%$ which is a decrease of $10 \%$.

\section{CONCLUSION}

This chapter discusses the differences and similarities between sets of plaster tests infused with rockwool and series infused with $E$ glass fibre of $25 \mathrm{~mm}$, all of them made with a relation between $\mathrm{W} / \mathrm{P}=0,6$.

\subsection{Workability}

During the production of the series of plaster tests infused with $\mathrm{E}$ glass fibre of $25 \mathrm{~mm}$, it is observed that from $2 \%$ addition the workability of the paste decreases.

The workability of the plaster tests infused with rockwool is good even for an addition rate of $4 \%$. Therefore it can be concluded that this property improves with the addition of rockwool, with respect to addition of E-glass fibre of $25 \mathrm{~mm}$.

\subsection{Hardness Shore C}

fig. 1 "Comparative Hardness Shore C- Weight"

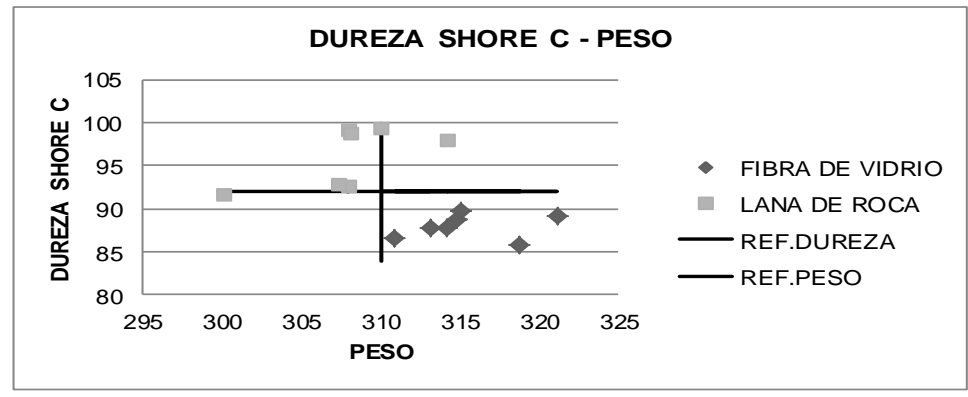

This shows that, for less weight, higher values of surface hardness are obtained in the series made with rockwool (that comes from recycling) than in the series made with the E-glass fibre (fig. 1).

\subsection{Bending strength}

fig 2 "Comparative Flexural Strength- Weight"

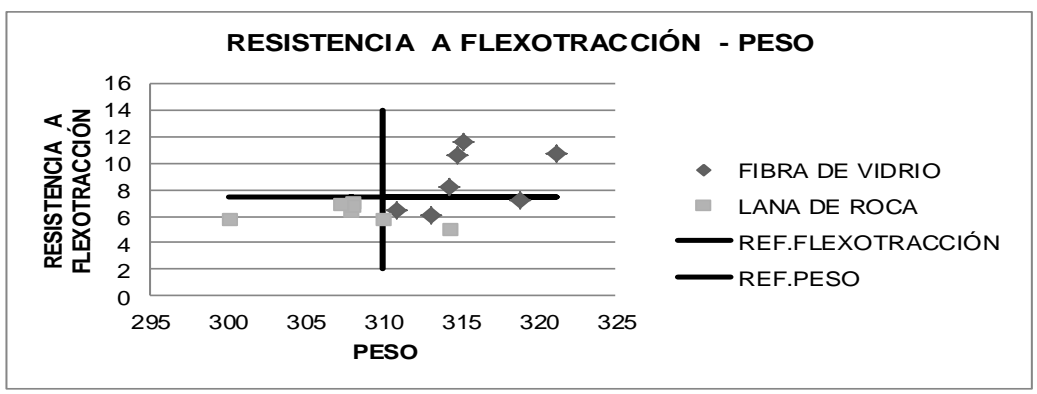


The plaster tests, infused with $E$ glass fibre, have more flexure strength than the infused with rockwool that comes from recycling (fig. 2). Test series infused with rockwool have less weight than the ones with E glass fibre.

\subsection{Compressive strength}

The series infused with rockwool from the recycling are more resistant to compression than the ones infused with $\mathrm{E}$ glass fibre. These ones have higher weight (fig. 3).

fig. 3 "Comparative Compressive Strength - Weight"

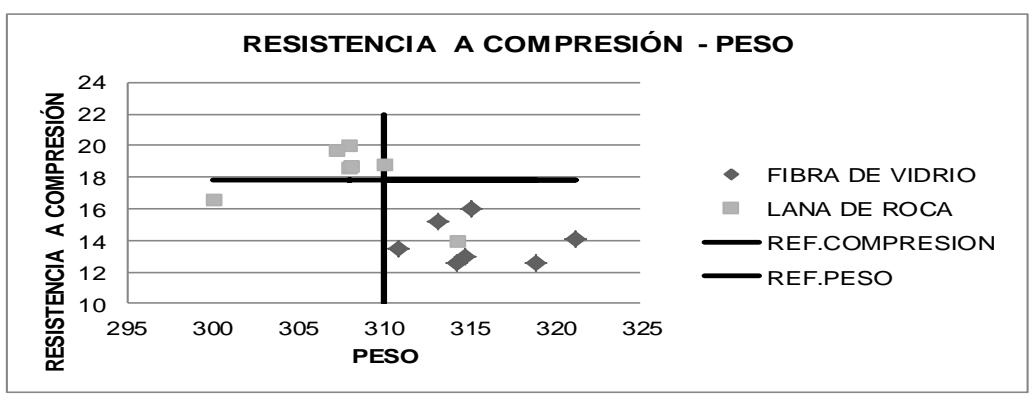

As a general conclusion it should be noted that the plaster tests infused with $\mathrm{E}$ glass fibre of $25 \mathrm{~mm}$ resist more than $62.87 \%$ in bend strength than those added with rockwool that comes from recycling with a percentage of addition of $4 \%$. Besides the two sides of the fracture surface are sewn, but it does not happen with the ones infused with rockwool.

By contrast, plaster samples with rockwool show better results than the ones that are added with $\mathrm{E}$ glass fibre of $25 \mathrm{~mm}$ in Shore $\mathrm{C}$ hardness, weight and resistance to compression.

Hardness Shore C: increases by almost $10 \%$ to the rates of addition of $1 \%, 1.5 \%$ and $2.5 \%$, with a lower weight in at all.

Weight: decreases to $3.63 \%$ for an addition rate of $4 \%$.

Compressive strength: increased up to $20.07 \%$ for an addition rate of $3 \%$, also with a minor weight

\section{FUTURE RESEARCH}

- Higher percentage of additives.

- Work with longer fibres.

- Study on adding other formats of rockwool (dust...).

- Work with other tissue types from the C\&DW.

- Mixture ventures between different types of fibres.

\section{REFERENCES}

[1] Primera Cumbre de la Tierra. (1992). Rio de Janeiro.

[2] Agenda 21. (1992).

[3] Reunión de Johannesburgo. (2002). 
[4] Real Decreto 105/ 2008, de 1 de febrero, por el que se regula la producción y gestión de los residuos de construcción y demolición. (1 de febrero de 2008).

[5] García Santos, A. (enero/febrero/marzo 2004). Aplicaciones constructivas de un material compuesto de escayola y fibras naturales de Typha Latifolia. Materiales de Construcción. CSIC. Incluida en el JCR del ISI. , ISSN 0465-2746, Vol. 54. № 273. Págs. 73-77.

[6] Haselein, R., \& otros. (2002). Fabricaçao de chapas de particulas aglomeradas usando gesso como material cimentante. Ciência Forestal, V.12, n.1, 81-87.

[7] Khedari, J., \& otros. (2001). New lighweight composite constructions materials with low thermal conductivity. Cement \& Concrete Composities, Elsevier Ltd.27: 41-47.

[8] Oteiza San José, I. (s.f.). Estudio del comportamiento de la escayola reforzada con fibras de sisal, para componentes en viviendas de bajo coste. Tesis Doctoral.

[9] García Santos, A. (Septiembre/Octubre 1988 ). Comportamiento mecánico de yeso reforzado con polímeros sintéticos. Informes de la Construcción. IETCC.CSIC. , ISSN 00200883, Vol. 40 № 397. págs. 67-91.

[10] Santos, A. G. (s.f.). Modelo teórico del comportamiento mecánico del yeso y sus compuestos fibrosos poliméricos. Tesis Doctoral.

[11] Alcaide, N. (1992). Yeso reforzado con fibra de vidrio y fluidificante. Cátedra de materiales de construcción. ETSAM.

[12] del Rio Merino, M. (s.f.). Elaboración y aplicaciones constructivas de paneles prefabricados de escayola aligerada y reforzada con fibras de vidrio $\mathrm{E}$ y otros aditivos. Tesis Doctoral.

[13] Remedios, J. (1989). Yeso reforzado con tejidos y velos de fibra de vidrio E . Cátedra de materiales de construcción. ETSAM.

[14] Sánchez, V. (1991). Yeso reforzado con fibra de vidrio en distintos porcentajes . Cátedra de materiales de construcción. ETSAM.

[15] del Río Merino, M. (2002). Patente no ES2170612A1, Yeso aligerado con corcho y su aplicación en paneles para construcción. . España, Madrid: OEPM.

[16] Hernandez Olivares, F., \& otros. (1999). Development of cork-gypsum composites for building applications. Construction and Building Materials, Elsevier Ltd. 27: 41-47.

[17] UNE EN 13279-2 yesos y productos de yeso para la construcción. Parte 2. Métodos de ensayo. 